\section{What goals for UK science?}

SIR - After many years as a scientist, I optimistically believe that the sciences have a vital part to play in the improvement of the 'human condition' and, by the way, in the regeneration of the British economy. I take it that this view is shared by the leaders of our profession. It comes as a disappointment, therefore, that all the responses to the Waldegrave initiative expressed by speakers at Nature's meeting on 19 March about the forthcoming White Paper on science confined themselves to the straitjacket of questions asked by the minister. Who ever heard a politician naively answer the question asked rather than expressing his or her own views?

One or two members of the audience likened the platform attitude to 'rearranging the deckchairs on the Titanic' and I must concur with that view. Is it too cynical to believe that the spokesmen of our profession are more concerned with the funding of their particular disciplines or institutions than with the wider aspects of the role of the sciences in our present predicament?

Why otherwise would every speaker take it upon himself to become an amateur economist, organizing the division of the research cake, rather than a professional scientist, enthusiastic about the role of science in regeneration and vigorously promoting its share and place in government? The public image of science is not particularly high, and until its most senior representatives defend and promote and, if they believe in it, expand its role, they will get the ministerial representation they deserve, well intentioned but powerless.

Alan Berman

Flat 2, 24 Church Crescent,

London N10 3ND, UK

\section{Still second class}

SIR - A perceptive letter, "Second class scientists?" (Nature 346, 213; 1990), drew attention to a $30-43$ per cent differential in salary for incumbents of a position at the University of Auckland according to whether their undergraduate training was medical or scientific. I hesitate to add to this picture, but it is only one aspect of a discrimination against biomedical scientists that is deeply entrenched in New Zealand's oldest and at present moribund medical faculty, that of the University of Otago.

In addition to the salary differential, incumbents with postgraduate qualifications are appointed as senior lecturer if medically trained but as lecturer if scien- tifically trained: this can be a 10-year seniority differential. Promotion is harder for scientists. A very productive member of my research unit, approved by her grant funding authority for promotion to senior research fellow, was denied promotion by the university. A medically trained colleague of the same age with a less impressive research record had previously been promoted to associate professor.

By persistence, some of us have reached the level of full professor. We do not receive a personal chair like our medically trained colleagues, or as we would in other faculties of the university. Instead, we are designated professorial research fellows, listed in the university calendar at the end of the staff list after lecturers and denied use of the title professor. A recommendation in 1991, by the four medical school deans, that professorial research fellows be given the right to use the title was vetoed by the vice chancellor's office of the University of Otago which controls three of the schools. This unfathomable pettiness was explained as a concern not to devalue the status of existing medical school staff. In truth, research fellows greatly overshadow corresponding staff in professional reputation. Rip van Winkle sleeps on soundly in Dunedin.

Peter H. Fitzgerald

Department of Pathology,

University of Otago,

Christchurch School of Medicine,

Christchurch, New Zealand

\section{SI units explained}

SIR - Two recent articles ${ }^{1,2}$ once more underline an apparent lack of understanding of the Système International d'Unités (SI).

The SI is an extension of the metre/ kilogram/second/ampere (MKSA) system proposed in 1950 . The implementation of SI when reporting clinical laboratory results has long been a concern of the International Union of Pure and Applied Chemistry (IUPAC) and the International Federation of Clinical Chemistry (IFCC) which recommended in $1966^{3}$ the litre as denominator in concentration units involving volume, amount of substance (unit mole) whenever possible, and preferential use of whole multiples of three as powers of ten. These recommendations do not advocate full implementation of SI but recommend restrictions by limiting the clinical laboratory to 'favoured' SI units.

Any measurement in science or medicine can be adequately and unambiguously expressed with SI units, and, with few exceptions, no basic change in units used in the clinical laboratory is mandated. SI does not stipulate that concentration measurements must use the $\mathrm{dm}^{3}$ (litre) as unit of volume, nor does SI stipulate that analyte concentration must be reported as substance concentration, that is $\mathrm{mole} / \mathrm{dm}^{3}$ (litre).

The articles "Americans retreat on SI units" 1 and "NEJM restricts use of SI units" 2 thus do not reflect accuracy in reporting, and contrasting "conventional units" with "SI units" is misleading. Within SI, expressing cholesterol concentration in $\mathrm{mg} / \mathrm{dL}$ is just as valid as expressing results in $\mathrm{mmol} / \mathrm{L}$. The only 'conventional' units in general use that are non-SI are the mm of mercury and the (international) unit for enzyme analyses.

More appropriate headings in the British Medical Journal and in Nature would thus have been: "Americans (NEJM) lift restrictions on the use of SI units".

0. W. van Assendelft

(Office of the Director, Scientific

Resources Program)

National Center for Infectious Diseases,

Centers for Disease Control

and Prevention,

US PHS, DHSS,

Atlanta, Georgia 30333, USA

1. Nylenna, M., \& Smith, R. Br. med. J. 305, 268, (1992). 2. Watson, T. Nature 359, 175 (1992).

3. Dybkaer, R. \& Jorgensen, K. Quantities and Units in Clinical Chemistry including Recommendations 1966 (Williams and Wilkins, Baltimore, 1967).

\section{Beyond belief}

SIR - Stuart Sutherland (Nature 361, 292; 1993) berates John Polkinghorne for berating Lewis Wolpert who berates the whole sorry business of science-andreligion, and I wish to God it would stop. What is the point to all this earnest repartee, this desperately serious selfaddressing, this Woolgathering in the Outer Homilies?

Most normal people cease such debate by the age of 14 , and even renowned British scientists, one cannot help hoping, should leave off at around 50 . Renowned British scientists who insist on believing that the Universe was created and is being maintained and guided by supernatural forces and/or beings whose nature lies forever beyond our comprehension are not going to be swayed by rational discourse, logical analysis, empirical evidence and sanity. If they were subject to these influences they would not believe the things they do in the first place and when they are also ordained priests they have embraced a style of now-you-see-it-now-you-don't in regard to Reason that is invincible to mere factual consideration, having long since soared beyond the gravitational pull of reality.

Ralph Estling

The Old Parsonage, Dowlish Wake,

IIminster, Somerset TA19 ONY, UK 